\title{
University students' perception of exposure to various English accents and their production
}

Percepción de la exposición a acentos del idioma inglés y su producción por parte de estudiantes universitarios

\author{
Volumen 19, Número 2 \\ Mayo-Agosto \\ pp. 1-19
}

\section{William Charpentier-Jiménez}

\section{Cite este documento así}

Charpentier-Jiménez, William. (2019). University students' perception of exposure to various

English accents and their production. Revista Actualidades Investigativas en Educación, 19(2), 1-19. Doi. 10.15517/aie.v19i2.36908 


\title{
University students' perception of exposure to various English accents and their production \\ Percepción de la exposición a acentos del idioma inglés y su producción por parte de estudiantes universitarios
}

\section{William Charpentier-Jiménez ${ }^{1}$}

\begin{abstract}
Resumen: This article presents students' perception of English accent varieties in a BA in English and a BA in English Teaching, both of the University of Costa Rica (UCR). The purpose of this study was to find out higher education students' opinions on the incorporation of further English accents in their major. Until now, this topic has not been deeply studied in the Costa Rican context. Results were obtained from a 16-point survey answered by 77 participants. Based on these results, the writer explains that a need to include a variety of native and non-native English accents exists and that a language program would benefit from it. The results demonstrate that $76.6 \%$ of students consider being able to imitate several types of English accents important, while 93.5\% believe that what is important is being able to recognize and understand several accents. Data show that the majority of students consider the incorporation of various types of accents in their major essential. In practical terms, these results should promote a curricular change where several types of English accents should be incorporated.
\end{abstract}

Palabras clave: bilingualism, intercultural communication higher education, English varieties, spoken language

\begin{abstract}
El presente artículo estudia la percepción del estudiantado sobre la variedad de acentos en inglés en un bachillerato en inglés y un bachillerato en la enseñanza del inglés, ambos de la Universidad de Costa Rica (UCR). Se busca con este artículo dilucidar la opinión de estudiantes de educación superior sobre la inclusión de otros acentos en inglés en su carrera universitaria. Hasta el momento, este tema no ha sido explorado a profundidad en el contexto costarricense. Los resultados se han obtenido de un cuestionario de 16 ítemes respondida por 77 participantes, tomando en cuenta datos cuantitativos en una investigación por encuesta. Basado en estos resultados, el autor explica que existe una necesidad de incluir una variedad de acentos en inglés, tanto nativos como no nativos, y que un programa de lengua se beneficiaría con su implementación. Los resultados demuestran que un $76.6 \%$ de los estudiantes considera importante aprender a imitar diferentes acentos en inglés, mientras que un 93.5\% menciona como importante aprender a reconocer y comprender diversos tipos de acentos. Estos resultados demuestran que la mayoría del estudiantado ve importante la inclusión de diferentes tipos de acentos en su programa de estudio. En términos prácticos, estos resultados deberían motivar una reforma curricular donde los cursos orales contengan actividades lingüísticas que incluyan diferentes tipos de acentos de manera progresiva.
\end{abstract}

Keywords: bilingüismo, comunicación intercultural, educación superior, variedades del inglés, lengua hablada

\footnotetext{
1 Profesor de la Universidad de Costa Rica, en la Escuela de Lenguas Modernas, Costa Rica. Maestría en Enseñanza del Inglés y Maestría en Administración Universitaria, ambas de la Universidad de Costa Rica.
}

Dirección electrónica: wcharpentier@gmail.com

Artículo recibido: 2 de octubre, 2018

Enviado a corrección: 5 de febrero, 2019

Aprobado: 11 de marzo, 2019 


\section{Introduction}

Oral communication has always been at the core of language teaching and learning. Being able to speak and understand what others say becomes crucial as interlocutors usually respond synchronically. Nevertheless, several aspects could hinder the communication process. Noise, deficient devices (phones, computers, or speakers), or even language barriers could cause communication breakdowns. In the context of individuals who seek to communicate in a second language, one of the main taxing aspects of communication is being able to interact fluently with people with different accents. Not understanding what someone else is saying due to accent differences may lead to embarrassment, rejection, or misunderstandings.

The present research paper aims at understanding university students' perceptions of language exposure and production in a BA program in English and a BA program in English Teaching. This topic deserves attention since "with an increased understanding of the variability and variation in Global Englishes, university students will be fully prepared to participate in ELF communication and embrace the wide range of possibilities afforded by ELF communication, including the enhancement of their intercultural understanding" (Sung, 2015 , p. 48). Two different groups will benefit from the findings of this project. On one hand, the institution and its language curriculum will obtain data regarding students' accent preferences and perceptions, which in turn may lead to curricular changes. On the other hand, students will learn how to distinguish and interact with people who communicate in English as a second or first language and whose accent differs from theirs. Accent exposure is particularly important in the context of international commerce and worldwide technological communication demands. Jenkins (2000) mentions that "English is now learnt and spoken most frequently to serve international functions among L2 speakers in international contexts" (p. 16). She argues that L1 speakers should not dictate standards for L2 speakers. One option mentioned by the author is to let English learners choose the variety of English they want to imitate based on personal desires. The only indispensable characteristic of any variety of the language is mutual intelligibility since "pronunciation appears to play a very major role in problematic interlanguage talk" (p. 19). Costa Rica already participates strongly in the context of international commerce and worldwide technological communication since "global corporations have built manufacturing plants in this country. High-tech, consumer goods, and pharmaceutical firms are represented and have grown thriving export driven 
organizations" (Orkin, 2014, p. 15). This in turn provides a global context where understanding a variety of English accents may help prevent a potential for communication breakdown. By knowing how students perceive accents and how to approach different types of accents in class, language programs will offer different contents and include innovative communicative activities.

Facing a foreign accent may interfere with word recognition in adults, especially if they have never been in contact with particular types of foreign or native English accents before. Schmale, Cristia, and Seidl, (2012) mention that "being exposed to multiple accents is likely to be an everyday occurrence in many societies, it is unexpected that such non-standard pronunciations would significantly impede language processing once the listener has experience with the relevant accent" (p. 732). In addition, Seidlhofer (2005) points out that "since roughly only one out of every four users of English in the world is a native speaker of the language (Crystal 2003), most ELF interactions take place among 'non-native' speakers of English" (p. 339). However, this is not often the case in many societies. In most Latin American countries, for example, universities and language institutes in general have usually favored Standard or Mainstream American English. With the exception of some British language institutes, in Costa Rica, classes and materials often present North American English (NAE) as the preferred type of English. Although it is not explicitly stated, the BA in English and the BA in English Teaching follow this trend. Materials, theory, and practice lead students to recognize and use NAE. The researcher does not intend to explore if or suggest that a language program should teach all or several variations of a language, but under the present circumstances where international commerce and worldwide communication directly impact the economy, it becomes necessary to understand the role of Global Englishes in the Costa Rican context. One first step to achieve this is to know students' opinions about accent production and understanding. Therefore, the underlying assumption of the current project is that students perceive a lack of accent exposure in their program and would approve the incorporation of at least some other accents as part of their instruction.

\section{Literature Review}

Pronunciation has several inherent elements that must be described in order to establish a clear context for the present research paper. One of those key elements is accent. According to Roach (2010) "this word is used (rather confusingly) in two different senses: 
accent may refer to prominence given to a syllable, usually by the use of pitch [or it may refer to] a particular way of pronouncing" (p. 3). Additionally, the term accent must be distinguished from dialect. Roach (2010) explains that accent pertains to the domain of pronunciation only, but the concept of dialect comprises differences in pronunciation (including accent), grammar, and vocabulary. Accordingly, Lippi-Green (1997) defines accents as "loose bundles of prosodic and segmental features distributed over geographic and/or social space" (p. 42). This paper follows the notion that accent is a distinctive and particular pronunciation of the same language that differentiates and characterizes groups of speakers. In this sense, accents are often linked to geographical or social distributions, as mentioned by Lippi-Green (1997). Nevertheless, the idea of an inherited accent, or one learned natively, should also be taken into account.

As regional variations, accents are not bound to foreign language learning. Every speaker of a language has an accent, and sometimes people are even able to adjust their speech to use or imitate a different accent. In terms of exposure, this research project pretends to cover accents in their broadest sense, taking into account native English language accents and non-native English language accents. In the analysis of American English, Ladefoged (2016) states that "there are many different dialects of English spoken in North America, so it is somewhat improper to refer to any one of them simply as 'American English"' (p. 41). This claim can serve as a basis for describing any type of English language variation. Nevertheless, this study roughly separates English language types according to broad regional similarities; therefore, the many different types of accents (native or nonnative) in each region are not taken into account.

Since accents denote particular pronunciation characteristics of groups of people, they could slow or even hinder communication. For Clarke and Garret (2004) foreign accent is "a source of variability in speech that can be particularly detrimental to speech perception" ( $p$. 3647). In this regard, Akmajian, Demers, Farmer, and Harnish (2010) distinguish between a communicative intention and a communicative act. A communicative intention occurs when a speaker attempts to deliver a message. On the other hand, a communicative act occurs "when a speaker succeeds at conveying a message by having his or her communicative intent recognized" (p. 82). When this is accomplished, speakers succeed at exchanging information. Different dialectical variations may, however, affect mutual intelligibility. Mutual intelligibility takes place when, despite using two variates of a language, speakers are able to 
communicate (Akmajian et al, 2010). The reason for exposing students to different accents is to optimize mutual intelligibility among both native and non-native speakers of English.

When analyzing the literature on accent exposure, there is a body of research addressing infant, native language variations and their implications. One such study has demonstrated positive results in accent exposure during other stages of life. Adank and Janse (2010) conducted a research study taking into account younger and older, monolingual, Dutch, listeners. Twenty younger adults, ranging from 18 to 41 years of age, and thirty older adults, ranging from 65 to 87 years of age, participated in this study. In order to investigate perceptual learning of a novel accent, the researchers presented the participants with 120 sentences in Standard Dutch and the same sentences in a novel, Dutch accent. Previous to the presentation of the sentences, the subjects were tested using auditory tests (such as hearing acuity and signal-to-noise ratio). Using a sound-proofed booth, the participants were tested individually. Each participant had to repeat the sentences they heard while an experimenter scored responders measuring the number of words repeated correctly. The researchers found out that, despite the fact that older listeners needed more time to adapt, they were able to adjust to new speech types. They also suggested that "the type of variation older listeners had to adapt to in the present study-accented speech-is a naturalistic one that they may (frequently) encounter in everyday life" (p. 739). Thus, these findings support the idea that age does not pose any problem to accent adaptability. This type of research proves that accent exposure could start at any time in life. Even for students who are 18 or older, as the target population of the present study, instruction that includes accents would prove beneficial in determining how they perceive accents and interact with other speakers.

In a similar study with adults and infants, Butler (2010) explored how exposure to regional and foreign accents affected adults' processing systems and how the developmental stages of language acquisition influenced adult accent perception capabilities. This study consisted of 11 experiments that sought to determine the short and long-term effects of exposure to different accents in adults' and infants' discrimination abilities for regional and foreign accents. All experiments were carried out with a different target population and followed three different tasks: a lexical decision task, a cross-modal matching task, and a preferential looking habituation task. The first two types of tasks were designed to be used with adults while the third one was used with infants, all under 10 months old. In general 
terms, the researcher concluded that adults "are rather good in perceiving differences between dialects [and] even excellent in imitating them" (p. 193). However, he also mentioned that for young infants, acquiring a second accent is far easier than it is for adults. These results validate the idea that adults would benefit from a systematic exposure to different accents. Students, for example, could learn the distinctive features present in various accents, and this could help them to be better prepared when they encounter accents different from their own in daily life situations.

As can be seen, research has often dealt with perception of accents rather than with what speakers believe or consider important when learning a second language. In these lines, Tanaka (2006) mentions that "most research on attitudes towards NNVEAs has focused on NSs' perspectives rather than on NNSs'; little work has examined the perspectives of people from areas where English is not generally used as L1"2 (p. 13). For this reason, Tanaka investigated "the attitudes of Japanese adult English learners towards varieties of English accents (VEAs) and the effects of their exposure to VEAs" (p. 3). The study included 48 Japanese ESL students and temporary workers between the ages of 18 and 30 years old. It included a combined research methodology. First, quantitative data was gathered through a questionnaire that asked for information related to the participants' background, previous exposure to VEAs, and current exposure to VEAs in the host country, Canada. After that, the researcher used individual, semi-structured interviews to gather qualitative information about past and present attitudes towards VEAs. His conclusions dealt with two main aspects. First, the researcher established a clear correlation between exposure to different accents and negative feelings towards them. Participants living in the host country, where English is the native language, demonstrated negative feelings towards non-native varieties of English, even their own Japanese variety. Other participants showed negative attitudes towards nonnative varieties of English or found them intimidating based on their exposure during the various learning stages. Besides improving learners' ability to communicate, cultural acceptance seems to be imbued with exposure to different accents since there is a clear relationship between speakers' accents and attitudes towards those accents. Second, and closely related to attitudes, the researcher mentioned that negative attitudes are closely related to the listening component. Tanaka's idea is that when students reach high listening

\footnotetext{
2 Throughout his study, the researcher uses the acronyms NVEA (native versions of English accents), NNVEA (non-native versions of English accents), NS (native speakers), and NNS (non-native speakers).
} 
proficiency, they tend to despise those accents that they cannot understand. This attitude could decrease "upon reaching high enough levels of English proficiency to understand a wide range of VEAs" (p. 104). Nonetheless, for students to reach that listening proficiency, they first need to be in contact with accents; moreover, instruction could guide students both in the acquisition of the listening skill and the cultural awareness component, which is actually required in intercultural communication.

In terms of international communication, Brabcová and Skarnitzl (2018) follow the concepts of inner, outer, and expanding circles. For these authors the "inner circle contains all speakers who use English as their L1, the outer circle refers to users for whom it is their second language (ESL), and the expanding circle is reserved for learners of English as a foreign language (EFL)" (p. 38). In their study, the researchers concentrated on EFL students' attitudes towards accents of English and their use as pronunciation models. More specifically, the study concentrates on finding out what "varieties of English should be, according to the respondents, presented to students in lessons" (р. 42). This project included 145 Czech participants whose ages ranged between 15 and 45 years old. Data were collected through a questionnaire that asked participants about some basic demographic information and attitudes related to different varieties of English. Brabcová and Skarnitzl (2018) present two main results in their paper. First, they mention that "over $70 \%$ of the respondents expressed a desire to acquire a native-like accent" (p. 45). The other $30 \%$ of students expressed that they do not wish to attain a native-like accent (15\%) or that they are unsure as to what type of accent they want to acquire (15\%). This shows that students favor theory and pronunciation practice that helps them improve their pronunciation to a native-like level. In terms of exposure, data shows that students "would like to acquire and that they should be exposed to many different accents, both native and non-native" (p. 48) and "that most participants would not prefer to be limited either to one native accent only, or exclusively to non-native accents of English" (47). Although the study does not state why students answered in this way, Brabcová and Skarnitzl (2018) point out that experts on pronunciation instruction should take this information into account when preparing English language lessons.

One last study related to students' attitudes towards NNVEAs was conducted by Sachiko (2009). The researcher mentions that "English is now used not only for communication among native speakers or between native and non-native speakers, but also for interactions between non-native speakers with different linguistic and cultural 
backgrounds" (p. 34). To discover students' attitudes towards American, British, and other varieties of English, the researcher worked with 56 Japanese, university students taking a Language and Culture course. In order to gather the required data, students listened to several audios where people used various types of English (e.g. Indian English, Singapore English, Scottish English, among others) to read the same passage. Students then completed a six-point questionnaire where they stated their impressions of each speaker's English using adjectives such as clear-unclear, careful-careless, and comprehensible-not comprehensible. Students also completed a seven-point rating scale to "survey subjects' ideas about English learning, the role of English, and anxiety in speaking English" (p. 38-39). The main findings of the study show that students view American and British English more positively than other varieties of English. Nevertheless, Sachiko (2009) mentions that the data also show that students perceive the role of English as a lingua franca as communicating with the inner circle only. Therefore, students do not take into account communication with the outer or expanding circles. Finally, the researcher concludes that if the main objective of university language programs is to help students communicate in an international setting, they should be exposed to different varieties of English through audios, movies, or international visitors. In addition to this proposal, the power of the Internet should also be considered. With the advent of ICT's, students could benefit from calls or video conferences with native and non-native speakers of English around the globe.

Research on accent exposure has been conducted based on different objectives. Most of the research found dealt with how infants distinguish different accents. Because of the subjects' age, what has been core to this body of research has been the infants' ability to differentiate and comprehend accents in the early stages of development. A second group of studies has tried to investigate comprehension in teenagers and adults. As in experiments with infants, the main objectives have been formulated to find how adults comprehend accents that are unfamiliar to them. Unlike infants, adults already have an established set of rules and sounds that guide them, and they are able to respond to differences in various manners. Finally, some studies have explored students' perceptions of different varieties of English at a university level. As mentioned earlier, much of this research has dealt with native varieties of English; only some studies have included non-native varieties of the language. 


\section{Method}

\subsection{Research design}

The present study follows a quantitative approach in which the survey research is used as the main technique to collect information. This descriptive investigation employed a webbased survey as the mode of data collection. A pilot test and a written consent where also used. Data was analyzed using frequencies and percentages.

\subsection{Participants}

A personal electronic mailing list of 92 students taking a third-year, oral course from the major was created during the first and second semesters of the academic year, in 2017. All students were enrolled in either the BA in English or the BA in English Teaching, both of the University of Costa Rica (UCR). Students from both majors take the same English oral courses. They were chosen since they have already taken six specific oral courses and have a clear notion of the language program. The list included students who were taking the course for the first time and agreed to participate in the study. All students were sent emails asking them to complete the survey. A total of 77 surveys were returned ( $83.69 \%$ return rate). Data from these surveys were collected and analyzed. No survey was kept from analysis. In case students had participated before and were taking the course for the second time, they were sent the survey only once. Participation in the study was voluntary.

The population included in this study is very particular. First, they are undergraduate, ESL learners whose native language is Spanish and who attend a public university. Second, students do not only learn the language but the rules that govern it. Therefore, at the end of the program, it is expected that they are able to use the language proficiently, and it is also expected that they can describe the language from a linguistic point of view. By the end of the major, students should be able to explain how English works employing concepts from the fields of morphology, phonetics, phonology, syntax, semantics, and pragmatics.

\subsection{Materials}

A printed written consent was created and distributed to invite students to participate. This consent was also sent to students electronically. A descriptive 16-item survey was developed to obtain information about students' perceptions of accent exposure in their major. A copy of the survey can be found at the end of this document (See Appendix A). The 
survey was pilot-tested with seven students with the same affiliation as the target population. It was later revised on the basis of the pilot-testing.

Each item on the survey was placed into one of the following three categories: (a) demographic information, (b) previous exposure to English accents, and (c) exposure to English accents in their classes. Two question formats were used in the survey, including forced choice and at least one open-ended questions. The survey included three types of questions: demographic, knowledge, and attitudinal questions. Most items were presented as checklists or Likert scales. For example, some items asked the participants to indicate how important they believed exposure to accents other than Standard American English (in oral courses) was for academic and work-related purposes. These items were rated on a 5-point Likert scale that included the following choices: 1=Not Important, 2=Slightly Important, 3=Moderately Important, 4=Important, and 5=Very Important. This type of scale format, or a similar one, was also used for other items in the survey. Some questions ask students to choose other types of English besides American English since American English is the language variation that almost all students in high school and all students at the university study. The total time to complete the survey materials was estimated from 10 to 15 minutes.

\subsection{Procedure}

This study used a quantitative study design. The researcher required permission to attend several classes and ask students for their participation. After briefly explaining the nature of the study, students were given a written consent. The researcher instructed them to read it, ask any questions they deemed necessary, and sign it if they wished to participate. After collecting all the consents, a list of 92 subjects who wished to participate was created. The first electronic mailing was sent to all 92 participants. The electronic mail included a copy of the written consent form addressed to the participants and a link to complete the survey. A second electronic mail was sent approximately one week after the first one. The purpose of this second mail was to thank those who had already completed the survey and encourage those who had not completed it to do it promptly. After two weeks, a final electronic mail was sent thanking all students for their participation, allowing the last few one more week to complete the survey, and offering research results to those interested. 


\section{Analysis of the Results}

The following description and analysis synthesize the students' perceptions towards accent exposure in the BA in English and the BA in English Teaching.

Table 1

Demographic Characteristics of Participant Sample, UCR, 2017

\begin{tabular}{|c|c|c|}
\hline Characteristic & $N$ & $\%$ \\
\hline Participants & 77 & - \\
\hline \multicolumn{3}{|l|}{ Age (in years) } \\
\hline Under 20 & 2 & 2.59 \\
\hline $20-24$ & 59 & 76.62 \\
\hline $25-29$ & 2 & 2.29 \\
\hline $30-34$ & 8 & 10.38 \\
\hline $35-39$ & 4 & 5.19 \\
\hline Not stated & 2 & 2.59 \\
\hline \multicolumn{3}{|l|}{ Gender } \\
\hline Woman & 46 & 59.74 \\
\hline Man & 31 & 40.25 \\
\hline \multicolumn{3}{|l|}{ Type of English user } \\
\hline NE & 1 & 1.29 \\
\hline ESL & 73 & 94.80 \\
\hline ETL & 3 & 3.89 \\
\hline
\end{tabular}

Note: $\mathrm{NE}$ = Native English, ESL = English as a Second Language; $\mathrm{ETL}=$ English as a Third Language Source: Compiled by author based on data gathered through students' answers, 2017

Table 1 summarizes students' demographic information. The information collected shows that student's age group is very homogenous. Additionally, the majority of learners acquired English as their second language.

In terms of previous exposure, i. e. before their second year in school, to other accents besides North American English, 46 students (59.7\%) asserted having been formally or informally exposed to other types of English accents. 31 students (40.3\%) mentioned they had never been exposed to any other type of accent. Those who have been exposed listed British English ( $n=34)$, Australian English ( $n=9)$, Indian English $(n=5)$, Canadian English ( $n$ $=4)$, and New Zealand English $(n=2)$ as the main types of native accent variations they have been in contact with. In terms of non-native variations, students mentioned having been in contact, at least one time, with Chinese, Russian, German, French, or Danish people who used English to communicate. Surprisingly, no student mentioned Latin American, non-native variations of English. This data demonstrate that an important sector of the English-learning population has not had any contact with different varieties of English. For those who have, 
British English is the main native variety, followed in a much lesser degree by other types. As a whole, exposure to non-native accents is not significant before students start their second year in school. In general, undergraduates tend to obviate that they also constantly interact in a non-native accent environment.

Among the sources of input, 37 students mentioned the media as the main source of exposure. Other sources of exposure listed were high school $(n=14)$, casual activities $(n=$ $14)$, travelling $(n=7)$, and workplace $(n=4)$. Only two responses included other language courses, conferences, or host families as sources of input. With the widespread use of the Internet and associated services, it is not surprising that the media stand out as the main source of input. It is also understandable that the workplace ranks low since, considering the students' age, not all of them are part of the workforce yet.

Further analysis was conducted to understand the students' perceptions of accent exposure in their classes. First, students were asked about four types of accents: native English accents (not including Standard North American English), regional United States accents, regional British accents, and non-native English accents. They were explicitly asked if their professors had designed activities that included any of the variations stated before. Table 2 summarizes students' responses.

Table 2

Types of English accent used in language activities, UCR, 2017 (Frequency and percentages)

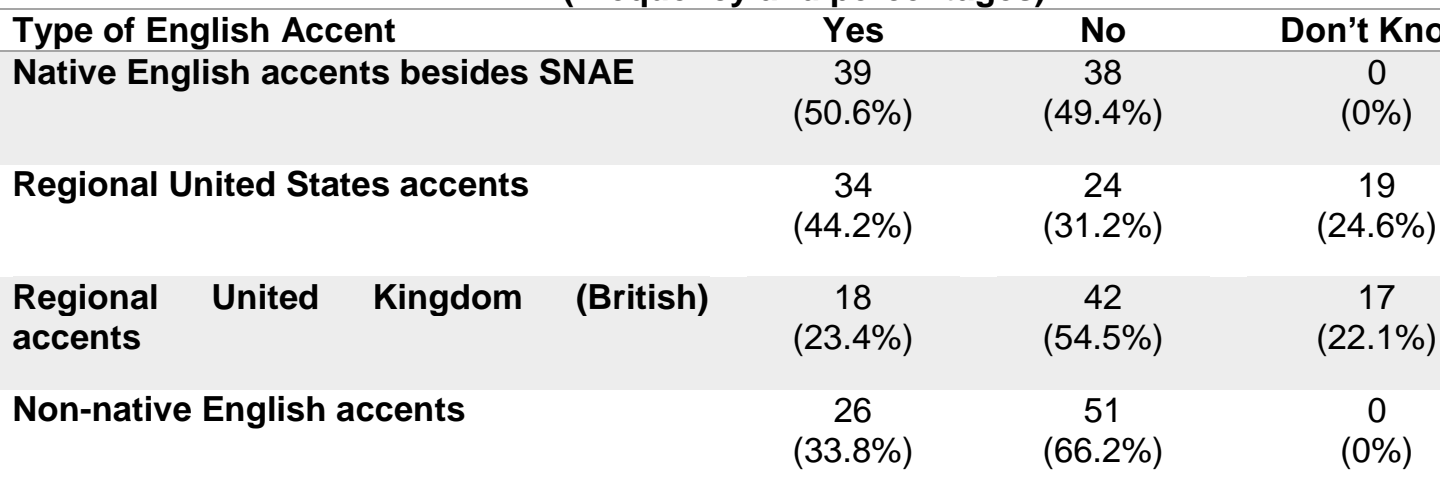

Note: SNAE = Standard American English

Source: Compiled by author based on data gathered through students' answers, 2017 
Table 2, shows that almost half of the population has not been in contact with any other type of native English besides Standard American English. The students also claim to have participated in very few activities that included regional United States accents, British regional accents, or non-native English variations. Those who had been in contact with other types of native accents in school mentioned variations of European English ( $n=34)$, North American English $(n=19)$, Asian English $(n=11)$, Oceanian English $(n=7)$, African English $(n=6)$, and Central and South American English $(n=7)$. This contrasts with the non-native varieties of English. In this case, the students listed European English $(n=18)$, Asian English $(n=16)$, North American English $(n=15)$, Central and South American $(n=12)$, and African English $(n$ $=4$ ) as non-native types of accents professors have used in their activities.

When the students were asked about how difficult it was to understand speakers with a different accent, most of them perceived it as a major factor when interacting with them. As can be seen in Figure 1, more than a quarter of the population labels understanding accents as difficult or very difficult. An important group (39\%) considered understanding accents moderately difficult, whereas $31.2 \%$ think it is slightly difficult or not difficult at all. Although important, these results should not be taken lightly since they do not show what specific types of accents students believe easier or more difficult to understand. It is possible that the students perceive British English or a Latin American variation easier than an Asian or African variation since they have been more in contact with the former variations.

Figure 1. Students' perception of difficulty level understanding accents, UCR, 2017
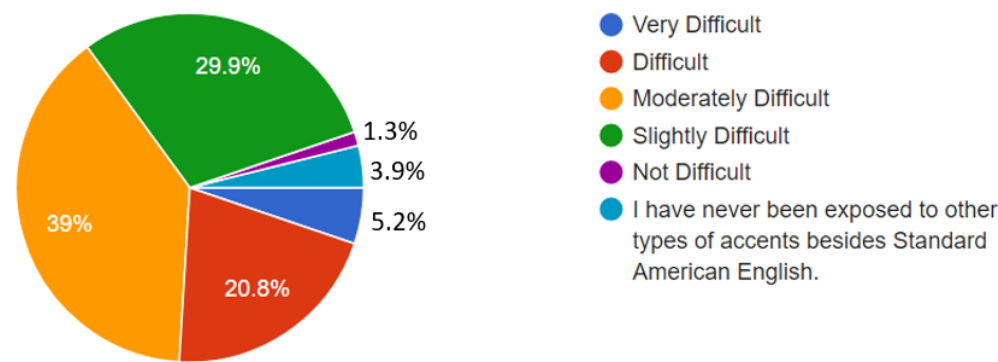

Source: Compiled by author based on data gathered through students' answers, 2017

In regard to importance, the students were asked two main questions. The first one was related to the ability to speak with a different accent. Figure 2 shows results for this item. From these data, it is possible to conclude that more than three-quarters of the total 
population under study believes being able to speak with different accents a great asset to their language abilities.

Figure 2. Students' perception of the importance level to speak with different accents, UCR, 2017

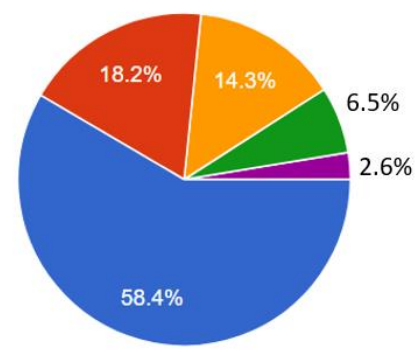

Very Important

Important

Moderately Important

Slightly Important

Not Important

Source: Compiled by author based on data gathered through students' answers, 2017

The second question focused on how important the students believed exposure to different accents is during their studies. In this case, the idea resides on being able to improve the listening ability and overall comprehension without necessarily developing the ability to imitate other types of accents. As shown in Figure 3, 93.5\% of the students favor exposure to different accents in oral courses.

Figure 3. Students' perception of importance of exposure to different accents, UCR, 2017
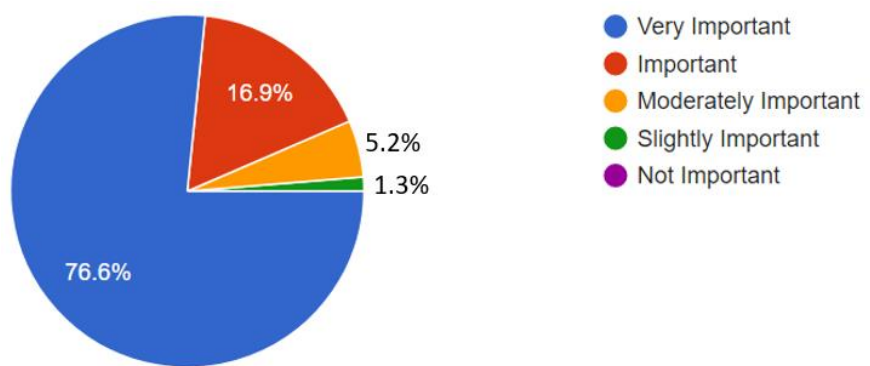

Source: Compiled by author based on data gathered through students' answers, 2017

Although results presented in Figure 2 and Figure 3 show a very clear tendency towards the inclusion of accents in the language program, exposure remains as a factor that students recognize as important but that has been often overlooked in oral language courses. 


\section{Discussion}

The results of this study provide significant information about the students' past and present experiences with accents, as well as their beliefs about accent exposure. First, the students reported that in past and present experiences around half of the activities did not include any type of English, besides American English. These results could mean that either professors are not prepared to deal with accent exposure in class or they have not seen a need for doing so. Such findings suggest the need for faculty training to address both the gaps in preparation and the importance of this topic. Other reasons could point to the lack of authentic or adapted materials that could be used in class or to time constraints most courses have. Nonetheless, finding out what reasons would motivate professors to a) include accent variations in their activities and b) decide how many and which varieties should be included deserves attention.

Second, data show that there are certain native English accents that have been included in language courses, but these numbers drop heavily when considering non-native English accents. Curriculum designers, and professors who assume the task of designing the curriculum, should decide, based on a needs analysis, what other native and non-native varieties of English are worth including. The purpose of this paper is not to suggest that all or a large number of accents should be included in the language program, nor does it intend to suggest that they should be included in lieu of standard variations of the language. Language programs should seek the proper balance, thinking about the students' needs and interests.

Third, evidence suggests that, when the students have had contact with different types of accents, they have considered the experience somewhat difficult. Research has confirmed that speakers who share different types of accents become slower and less accurate during language exchanges (Adank, Evans, Stuart-Smith, and Scott, 2009; Floccia, Goslin, Girard, and Konopczynski, 2006; Munro and Derwing, 1995). Nevertheless, exposure, on the other hand, helps listeners to adapt and interact with fewer misunderstandings and at a more natural pace (Dahan, Drucker, and Scarborough, 2008; Skoruppa and Peperkamp, 2011). Madárová (2017) adds that "related to the curriculum of the English language courses, it should be reconsidered from the point of view of EIL and the aim to understand the wide variety of accents of non-native speakers should be respected as nowadays, non-native speakers speak more frequently with nonnative speakers that native speakers" (p. 35). The main objective of language courses should be, in general, to prepare students to interact in 
real life situations with native and non-native speakers of English. Therefore, the perceived difficulty the students have faced should be addressed during instruction, so they are prepared to face out-of-class challenges.

Finally, the students indicated a solid tendency toward being exposed to accents as part of their studies. As mentioned before, people in charge of the curriculum should decide what types of accents should be incorporated. Moreover, they should decide what role accents play in the students' preparation. On one hand, an important group of students has suggested that activities should help them to imitate accents. This, in turn, could take more time to accomplish and also require the creation of both receptive and productive activities. Additionally, and taking into account that a higher number of the students believe exposure to be more significant, faculty in charge of the curriculum should vent the necessity to introduce the most important types of accents and include listening activities to this effect.

In this sense, the existent six-course program (Appendix B) could implement all of the ideas above and be specifically tailored to the students' needs. Table 3 presents a draft of a proposal, based on answers given by the students to questions 7 and 9 .

Table 3.

Possible distribution of types of English accents used in language activities, UCR, 2017

\begin{tabular}{|c|c|c|}
\hline Course & English Accent & Examples \\
\hline Oral Course I & Standard North American English & - \\
\hline Oral Course II & United States Regional Variations & $\begin{array}{c}\text { Greater New York City, North- } \\
\text { Central, and South-Eastern }\end{array}$ \\
\hline Oral Course III & Received Pronunciation & \\
\hline Oral Course IV & British Regional Variations & $\begin{array}{c}\text { Cockney, West Midlands, and } \\
\text { Northern England }\end{array}$ \\
\hline Oral Course V & Other Native Variations & $\begin{array}{c}\text { Canada, India, New Zealand, and } \\
\text { Australia }\end{array}$ \\
\hline Oral Course VI & Non-native Variations & $\begin{array}{c}\text { Asia (China, Japan, Korea) and } \\
\text { Europe (France, Germany, } \\
\text { Russia), Latin America (Mexico, } \\
\text { Argentina, Brazil) }\end{array}$ \\
\hline
\end{tabular}

Source: Compiled by author, 2017 Argentina, Brazil)

Since this proposal does not exclude Standard American English, in this case in particular, it is advisable to decide on the weight each type of English would have. As a starting point, professors could pilot-test an $80 \%$ to $20 \%$ distribution, where Standard American English (or the common-core variety) accounts for $80 \%$ of the program and $20 \%$ for each variety according to the course being taught. Follow-up research must be conducted to validate the outcome of such proposal. 
Future research is also needed to determine what accent varieties should be given more emphasis and which give students more trouble. A possible procedure to determine difficulty may be to prepare diagnostic, listening tests where students have the chance to respond to auditory input in a controlled environment. This data could provide information about what accent varieties deserve more attention based on difficulty. In terms of importance, workplace and graduate-student survey studies could be conducted to figure out what types of linguistic interactions students have and who their interlocutors are. Once both parameters are established, a correlation can be drawn.

There are some limitations in this study. Suggestions and implications above were based on the study concerning students' perceptions on exposure and possible pronunciation of different types of English. This paper did not explore effects of supplementary linguistic features such as vocabulary and spelling, grammar usage, semantic elements, or pragmatics. Other limitations of this study are concerned with research methodology. First, the number of students who participated in the study was limited. The unique characteristics of the population (ESL students learning the language and learning linguistic elements of English) make the conclusions difficult to replicate or apply in other ESL settings where students do not necessarily use in-depth metalanguage. Finally, it is important to acknowledge that students may not know exactly what types of English they have been exposed to in different courses. Students may simply not remember or ignore what specific types of English professors have used in different activities. Additionally, they may be idealistic on the number of varieties of English one person may be able to adapt to.

The researcher encourages other higher education institutions where ESL or EFL is taught, especially those out of the Latin American context, to replicate this study. It is imperative for any institution to attain linguistic objectives based on students' needs. The case for accent exposure should not be taken lightly as "learning to quickly process accented speech is a prerequisite to successful communication" (Cristia et al, 2012, 354). Experts in charge of curricular design should remember that "unfamiliar accents initially impair linguistic processing by infants, children, younger adults, and older adults, but listeners of all ages come to adapt to accented speech." (Cristia et al, 2012, p. 354). The purpose of language programs should always be to prepare students in the best way possible and help them adapt in the controlled, guided, and more amicable environment of the language class so that they are better prepared to face real world communicative situations in a better way. 


\section{References}

Adank, Patti; and Janse, Esther. (2010). Comprehension of a novel accent by young and older listeners. Psychology and Aging, 25(3), 736. Retrieved from https://searchproquest-com.ezproxy.sibdi.ucr.ac.cr/docview/757185150?accountid=28692

Adank, Patti; Evans, Bronwen; Stuart-Smith, Jane; and Scott, Sophie (2009). Comprehension of familiar and unfamiliar native accents under adverse listening conditions. Journal of Experimental Psychology: Human Perception and Performance, 35(2), 520-529. Doi: http://dx.doi.org/10.1037/a0013552

Akmajian, Adrian; Demers, Richard; Farmer, Ann; and Harnish, Robert. (2010). Linguistics: An Introduction to Language and Communication (6th ed.). United States of America: The MIT Press

Brabcová, Kateřina. and Skarnitzl, Radek. (2018). Foreign or Native-like? The Attitudes of Czech EFL Learners Towards Accents of English and Their Use as Pronunciation Models. Studie z aplikované lingvistiky - Studies in Applied Linguistics. 9(1), 38-50.

Butler, Joseph Patric. (2010). Perception of accents and dialects in adults and infants (Order No. U515105). Available from ProQuest Dissertations and Theses Global: Health and Medicine. (899749903). Retrieved from https://search-proquestcom.ezproxy.sibdi.ucr.ac.cr/docview/899749903?accountid=28692

Clarke, Constance and Garrett, Merill. (2004). Rapid adaptation to foreign-accented English. The Journal of the Acoustical Society of America, 116(6), 3647-3658. Doi: http://doi.org/10.1121/1.1815131

Crystal, David. (2003). English as a Global Language (2nd ed.). Cambridge: Cambridge University Press

Cristia, Amanda; Seidl, Amanda; Vaughn, Charlotte; Schmale, Rachel; Bradlow, Ann; and Floccia, Caroline. (2012). Linguistic processing of accented speech across the lifespan. Frontiers in Cognition, 3, 479. Doi: http://doi.org/10.3389/fpsyg.2012.00479

Dahan, Delphine; Drucker, Sarah; and Scarborough, Rebecca. (2008). Talker adaptation in speech perception: Adjusting the signal or the representations?. Cognition, 108, 710718. https://www.sciencedirect.com/science/article/pii/S0010027708001546

Floccia, Caroline; Goslin, Jeremy; Girard, Frédérique; and Konopczynski, Gabrielle. (2006). Does a regional accent perturb speech processing? Journal of Experimental Psychology: Human Perception and Performance, 32(5), 1276-1293. http://dx.doi.org/10.1037/0096-1523.32.5.1276

Jenkins, Jennifer. (2000). The phonology of English as an international Language, CUP: Cambridge. 
Ladefoged, Peter. (2016). American English in International Phonetic Association (Ed.), Handbook of the International Phonetic Association (18th Ed., pp. 41-44). United States of American: Sheridan Books.

Lippi-Green, Rosina. (1997). English with an accent: language, ideology, and discrimination in the United States. London: Routledge.

Madárová, Ingrid. (2017). Teaching English as an International Language in the Context of International Communication. English Matters VIII (a collection of papers). (pp. 34-44).

Munro, Murray and Derwing, Tracey. (1995). Foreign accent, comprehensibility, and intelligibility in the speech of second language learners. Language Learning, 45(1), 7397. http://dx.doi.org/10.1111/j.1467-1770.1995.tb00963.x

Orkin, Neil. (2014). Focus on Costa Rica. Training, 51(6), 15. Retrieved from https://searchproquest-com.ezproxy.sibdi.ucr.ac.cr/docview/1627751080?accountid=28692

Roach, Peter. (2010). English phonetics and phonology: A practical course. Cambridge: Cambridge University Press.

Sachiko, Miura. (2009). University students' attitudes toward varieties of English. The Tsuru University Review, 70, 33-48.

Seidlhofer, Barbara. (2005). English as a lingua franca. ELT Journal, 59(4), 339-341. Doi: https://doi.org/10.1093/elt/cci064

Schmale, Rachel; Cristia, Alejandrina; and Seidl, Amanda. (2012). Toddlers recognize words in an unfamiliar accent after brief exposure. Developmental Science (Online), 15(6), 732-738. doi:http://dx.doi.org.ezproxy.sibdi.ucr.ac.cr:2048/10.1111/j.14677687.2012.01175.x

Skoruppa, Katrin and Peperkampb, Sharon. (2011). Adaptation to Novel Accents: Feature-Based Learning of Context-Sensitive Phonological Regularities. Cognitive Science, 35, 348-366. doi:10.1111/j.1551-6709.2010.01152.x

Sung, Chit Cheung Matthew. (2015). Implementing a global Englishes component in a university English course in Hong Kong. English Today, 31(4), 42-49. doi:http://dx.doi.org.ezproxy.sibdi.ucr.ac.cr:2048/10.1017/S0266078415000383

Tanaka, Shoko. (2006). Exposure to varieties of English accent: Attitudinal changes among Japanese adult learners of English (Order No. MR16331). Available from ProQuest Dissertations and Theses Global: Literature and Language; ProQuest Dissertations and Theses Global: Social Sciences. Retrieved from https://search-proquestcom.ezproxy.sibdi.ucr.ac.cr/docview/304924486?accountid=28692

van Heugten, Marieke and Johnson, Elizabeth. (2016). Toddlers' word recognition in an unfamiliar regional accent: The role of local sentence context and prior accent exposure. Language and Speech, 59(3), 353-363. doi:http://dx.doi.org.ezproxy.sibdi.ucr.ac.cr:2048/10.1177/0023830915600471 


\section{Revista indizada en}
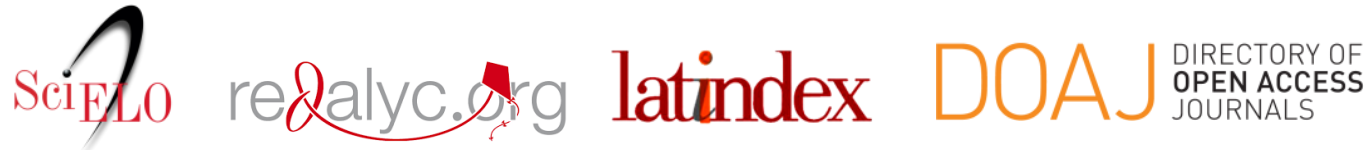

Distribuida en las bases de datos:

- Dialnet

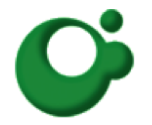
SHERPA/RøMEO

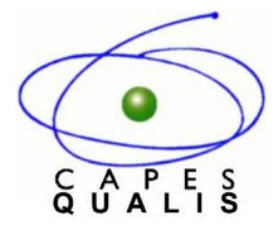

MIAR 